\title{
Effect of Plant Age on the Bacterial Spot of Bottle Gourd and Pumpkin Caused by Xanthomonas cucurbitae
}

\author{
Arpana Sharma, Kumud Jarial ${ }^{*}$ and R. S. Jarial \\ College of Horticulture and Forestry, Dr. Yashwant Singh Parmar University of Horticulture \\ and Forestry, Neri, Hamirpur (HP), India \\ *Corresponding author
}

\begin{abstract}
A B S T R A C T
Keywords

Bacterial leaf spot,

Cucurbits,

Xanthomonas

cucurbitae, Plant

age, Bottle gourd

and pumpkin, Adult

plant resistance

Article Info

Accepted:

16 November 2020

Available Online:

10 December 2020

Bacterial leaf spot impelled by Xanthomonas cucurbitae (Ex. Bryan) Vauterin et $a l$ is the most important disease of cucurbits especially in bottle gourd and pumpkin. To study the effect of plant age on disease development, the seedlings of bottle gourd and pumpkin were inoculated with standard bacterial suspension $\left(10^{8}\right.$ $\mathrm{cfu} / \mathrm{ml}$ ) through pin prick spray method after the plants attained the age of 10, 20, $30,40,50$ and 60 days. The mean disease severity in both bottle gourd and pumpkin was found to reduce with increase in age of plant viz. $10(59.62 \%$ and $65.33 \%$, respectively), 20 (53.81\% and $56.55 \%$, respectively), 30 (48.57\% and $51.42 \%$, respectively), 40 ( $42.83 \%$ and $40.39 \%$, respectively), 50 (39.16\% and $36.28 \%$, respectively) and 60 (33.98\% and $33.78 \%$, respectively) days old plants. The plants of bottle gourd and pumpkin at the age of 10,20, and 30 days were more susceptible to infection as compared to the older plants (40,50 and 60 days old) which exhibited the presence of adult plant resistance in both the crops against $X$. cucurbitae.

\section{Introduction}

Bacterial leaf spot of cucurbits, caused by Xanthomonas cucurbitae (Ex. Bryan) Vauterin et al., (Syn.: X. campestris pv. cucurbitae) is the one of the most important diseases of bottle gourd and pumpkin (Jarial et al., 2011 and Babadoost and Ravanlou, 2012). This bacterial disease was first time noticed on "Hubbard squash" in New York in the year 1926 (Bryan, 1930). The disease was also identified in many cucurbits like squash, cucumber, watermelon, prince melon,

pumpkin and bottle gourd from various parts of the world (Robbs et al., 1972; Anonymous, 1975; Taketani et al 1976; Maringoni et al; 1988; Sinha, 1989; Alippi, 1989; Li, 1990; William and Zitter, 1996; Pruvost et al., 2009; Pruvost et al., 2009; Lamichhane et al., 2010; Jarial et al., 2011; Dutta et al., 2013; Trueman et al., 2014; Liu et al., 2016; Liu et al., 2016 and Altin et al., 2020). This disease has been reported to cause huge losses in cucurbits approximately 50-60 per cent at the time of storage of pumkin fruit (Larazev, 2009). High yield loss (approximately 10.07 to $70.61 \%$ )
\end{abstract}


has been recorded in case of bottle gourd by Jarial et al., (2011). Nationally and internationally, the disease is of economic importance in bottle gourd and pumpkin, respectively.

The response of any host plant towards pathogen attack generally is dependent on the growth stage of the plant at the time of pathogen inoculation (Whalen, 2005). Generally, there is an increase in incubation period and decrease in disease severity of any disease with increase in age (Kendrick and Walker, 1948). The host susceptibility response in relation to developmental growth stage at the time of infection has been named as ontogenic resistance, developmental resistance, mature-seedling resistance, adult-seedling resistance, adult-plant resistance and occasionally, age-related resistance (Kus et al., 2002 and Whalen, 2005). Host phenology has been shown to affect the ecological interactions of plants, including changes in susceptibility of plants to disease (Farber and Mundt, 2017).

The host - pathogen relationship is affected by plant age and physiological plant age has a greater influence on the expression of host susceptibility as compared to chronological age (Dhingra and Sinclair, 2017). Older plants may show symptoms upon inoculation but later, recover and grow to maturity (Mitchell et al., 1978). Till date, the information on the infection efficiency of $X$. cucurbitae on the cucurbit plants of different age groups is not available in the literature Therefore, present investigations were conducted with an objective to study the effect of plant age on the development of bacterial spot in bottle gourd and pumpkin.

\section{Materials and Methods}

To study the effect of plant age on disease development, seeds of bottle gourd hybrid I and pumpkin hybrid I were sown in black plastic pots $(16 \mathrm{~cm} \times 8.5 \mathrm{~cm} \times 12.5 \mathrm{~cm})$. The seedlings of bottle gourd and pumpkin were inoculated with standard bacterial suspension $\left(10^{8} \mathrm{cfu} / \mathrm{ml}\right)$ through pin prick spray method after the plants attained the age of 10, 20, 30, 40, 50 and 60 days. All the treatments were replicated thrice. Data were recorded in terms of incubation period and disease severity (\%) up to 10 days after symptom appearance. Apparent infection rate (Van der Plank, 1963) and AUDPC (Shanner and Finney, 1970) were further calculated.

All experiments on effect of plant age on disease development was conducted in the Plant Pathology laboratory of the college in completely randomized design with three replications for each treatment and statistically analyzed by using online software OPSTAT.

\section{Results and Discussion}

Data presented in Table 1 revealed that in case of bottle gourd plants, mean incubation period was shortest $(47.66 \mathrm{~h})$ in 10 days old plants which was statistically at par with mean incubation period (48.66 $\mathrm{h}$ ) recorded in 20 days old plants. However, the incubation period was significantly longer on the plants of the remaining age groups. Although, maximum mean incubation period $(72.00 \mathrm{~h})$ was recorded in 60 days old plants which was statistically at par with mean incubation period $(71.33 \mathrm{~h})$ recorded in 50 days old plants.

It is further clear from the table that in case of bottle gourd, irrespective of days of observation, significantly maximum mean disease severity (59.62\%) was recorded in 10 days old plants followed by $20(53.81 \%), 30$ $(48.57 \%), 40(42.17 \%), 50(39.06 \%)$ and in $60(34.73 \%)$ days old plants (PLATE 1). 
Table.1 Effect of plant age on the development of bacterial leaf spot in bottle gourd

\begin{tabular}{|c|c|c|c|c|c|c|c|c|c|c|}
\hline \multirow{2}{*}{$\begin{array}{c}\text { Age of plant } \\
\text { (days) }\end{array}$} & \multirow{2}{*}{$\begin{array}{c}\text { Incubation } \\
\text { period } \\
\text { (hours) }\end{array}$} & \multicolumn{6}{|c|}{ Mean disease severity (\%) after days of disease appearance } & \multirow{2}{*}{$\begin{array}{c}\text { Overall } \\
\text { mean }\end{array}$} & \multirow[t]{2}{*}{ AUDPC } & \multirow{2}{*}{$\begin{array}{c}\text { Apparent } \\
\text { infection } \\
\text { rate } \\
\text { (per unit } \\
\text { per day) }\end{array}$} \\
\hline & & 0 & 2 & 4 & 6 & 8 & 10 & & & \\
\hline 10 & 47.66 & $\begin{array}{c}6.00 \\
(14.04)\end{array}$ & $\begin{array}{c}32.00 \\
(34.43)\end{array}$ & $\begin{array}{c}57.33 \\
(49.20)\end{array}$ & $\begin{array}{c}71.33 \\
(57.60)\end{array}$ & $\begin{array}{c}92.75 \\
(74.35)\end{array}$ & $\begin{array}{c}98.33 \\
(83.15)\end{array}$ & $\begin{array}{c}59.62 \\
(52.13)\end{array}$ & 3.06 & 0.66 \\
\hline 20 & 48.66 & $\begin{array}{c}4.86 \\
(12.70)\end{array}$ & $\begin{array}{c}29.33 \\
(32.76)\end{array}$ & $\begin{array}{c}53.12 \\
(46.77)\end{array}$ & $\begin{array}{c}61.42 \\
(51.60)\end{array}$ & $\begin{array}{c}82.82 \\
(65.50)\end{array}$ & $\begin{array}{c}91.33 \\
(72.95)\end{array}$ & $\begin{array}{c}53.81 \\
(47.04)\end{array}$ & 2.75 & 0.54 \\
\hline 30 & 51.33 & $\begin{array}{c}3.33 \\
(10.51)\end{array}$ & $\begin{array}{c}20.65 \\
(27.01)\end{array}$ & $\begin{array}{c}46.38 \\
(42.91)\end{array}$ & $\begin{array}{c}53.53 \\
(47.00)\end{array}$ & $\begin{array}{c}79.41 \\
(63.04)\end{array}$ & $\begin{array}{c}88.14 \\
(69.83)\end{array}$ & $\begin{array}{c}48.57 \\
(43.38)\end{array}$ & 2.45 & 0.55 \\
\hline 40 & 60.66 & $\begin{array}{c}2.50 \\
(9.05)\end{array}$ & $\begin{array}{c}34.01 \\
(35.66)\end{array}$ & $\begin{array}{c}42.77 \\
(40.82)\end{array}$ & $\begin{array}{c}49.86 \\
(44.90)\end{array}$ & $\begin{array}{c}57.27 \\
(49.16)\end{array}$ & $\begin{array}{c}66.66 \\
(54.71)\end{array}$ & $\begin{array}{c}42.17 \\
(39.05)\end{array}$ & 2.18 & 0.44 \\
\hline 50 & 71.33 & $\begin{array}{c}6.42 \\
(14.67)\end{array}$ & $\begin{array}{c}30.36 \\
(33.42)\end{array}$ & $\begin{array}{c}33.43 \\
(35.31)\end{array}$ & $\begin{array}{c}44.78 \\
(41.98)\end{array}$ & $\begin{array}{c}54.74 \\
(47.70)\end{array}$ & $\begin{array}{c}64.66 \\
(53.50)\end{array}$ & $\begin{array}{c}39.06 \\
(37.76)\end{array}$ & 1.97 & 0.33 \\
\hline 60 & 72.00 & $\begin{array}{c}6.98 \\
(15.50)\end{array}$ & $\begin{array}{c}16.34 \\
(23.83)\end{array}$ & $\begin{array}{c}29.31 \\
(32.76)\end{array}$ & $\begin{array}{c}40.95 \\
(39.77)\end{array}$ & $\begin{array}{c}52.14 \\
(46.21)\end{array}$ & $\begin{array}{c}62.66 \\
(52.31)\end{array}$ & $\begin{array}{c}34.73 \\
(35.06)\end{array}$ & 1.73 & 0.31 \\
\hline Overall mean & & $\begin{array}{c}5.01 \\
(12.71)\end{array}$ & $\begin{array}{c}27.11 \\
(31.18)\end{array}$ & $\begin{array}{c}43.72 \\
(41.30)\end{array}$ & $\begin{array}{c}53.64 \\
(47.14)\end{array}$ & $\begin{array}{c}69.85 \\
(57.66)\end{array}$ & $\begin{array}{c}78.63 \\
(64.41)\end{array}$ & & & \\
\hline CD $\mathrm{p} \geq 0.05$ & 1.58 & $\begin{array}{l}\text { Age of plan } \\
\text { Days of obs } \\
\text { Age of plan }\end{array}$ & on of obse & & .05 & (d) & & & $\begin{array}{c}\text { CD } \mathrm{p} \geq 0.05 \\
0.02 \\
\text { S.E (d) } 0.01\end{array}$ & 0.012 \\
\hline
\end{tabular}

Figures in parentheses are arcsine transformed values 
Table.2 Effect of plant age on the development of bacterial leaf spot in pumpkin

\begin{tabular}{|c|c|c|c|c|c|c|c|c|c|c|}
\hline \multirow{2}{*}{$\begin{array}{l}\text { Age of plant } \\
\text { (days) }\end{array}$} & \multirow{2}{*}{$\begin{array}{c}\text { Incubation } \\
\text { period } \\
\text { (hours) } \\
\end{array}$} & \multicolumn{6}{|c|}{ Mean disease severity (\%) after days of disease appearance } & \multirow{2}{*}{$\begin{array}{c}\text { Overall } \\
\text { mean }\end{array}$} & \multirow[t]{2}{*}{ AUDPC } & \multirow{2}{*}{$\begin{array}{c}\text { Apparent infection } \\
\text { rate } \\
\text { (per unit per day) }\end{array}$} \\
\hline & & 0 & 2 & 4 & 6 & 8 & 10 & & & \\
\hline 10 & 48.00 & $\begin{array}{c}4.33 \\
(11.99)\end{array}$ & $\begin{array}{c}37.33 \\
(37.64)\end{array}$ & $\begin{array}{c}60.66 \\
(51.13)\end{array}$ & $\begin{array}{l}95.00 \\
(77.16)\end{array}$ & $\begin{array}{c}96.33 \\
(79.43)\end{array}$ & $\begin{array}{c}98.33 \\
(83.15)\end{array}$ & $\begin{array}{c}65.33 \\
(56.75)\end{array}$ & 3.38 & 0.72 \\
\hline 20 & 49.66 & $\begin{array}{c}4.66 \\
(12.41)\end{array}$ & $\begin{array}{c}29.33 \\
(32.77)\end{array}$ & $\begin{array}{c}56.66 \\
(48.81)\end{array}$ & $\begin{array}{c}70.66 \\
(57.18)\end{array}$ & $\begin{array}{c}80.66 \\
(63.89)\end{array}$ & $\begin{array}{c}97.32 \\
(81.03)\end{array}$ & $\begin{array}{c}56.55 \\
(49.35)\end{array}$ & 2.88 & 0.65 \\
\hline 30 & 51.33 & $\begin{array}{c}3.33 \\
(10.51)\end{array}$ & $\begin{array}{c}27.33 \\
(31.50)\end{array}$ & $\begin{array}{c}45.33 \\
(42.30)\end{array}$ & $\begin{array}{c}59.86 \\
(50.67)\end{array}$ & $\begin{array}{c}77.33 \\
(61.54)\end{array}$ & $\begin{array}{c}95.33 \\
(77.55)\end{array}$ & $\begin{array}{c}51.42 \\
(45.68)\end{array}$ & 2.58 & 0.63 \\
\hline 40 & 63.33 & $\begin{array}{c}2.33 \\
(8.74)\end{array}$ & $\begin{array}{c}24.66 \\
(29.76)\end{array}$ & $\begin{array}{c}41.33 \\
(39.99)\end{array}$ & $\begin{array}{c}50.53 \\
(45.28)\end{array}$ & $\begin{array}{c}56.18 \\
(48.53)\end{array}$ & $\begin{array}{c}67.33 \\
(55.12)\end{array}$ & $\begin{array}{c}40.39 \\
(37.90)\end{array}$ & 2.07 & 0.47 \\
\hline 50 & 71.33 & $\begin{array}{c}2.00 \\
(8.12)\end{array}$ & $\begin{array}{c}20.33 \\
(26.79)\end{array}$ & $\begin{array}{c}30.73 \\
(33.65)\end{array}$ & $\begin{array}{c}45.33 \\
(42.30)\end{array}$ & $\begin{array}{c}54.66 \\
(47.65)\end{array}$ & $\begin{array}{c}64.66 \\
(53.50)\end{array}$ & $\begin{array}{c}36.28 \\
(35.34)\end{array}$ & 1.86 & 0.44 \\
\hline 60 & 72.00 & $\begin{array}{c}1.93 \\
(7.98)\end{array}$ & $\begin{array}{c}16.80 \\
(24.18)\end{array}$ & $\begin{array}{c}28.00 \\
(31.93)\end{array}$ & $\begin{array}{c}40.66 \\
(39.60)\end{array}$ & $\begin{array}{c}52.66 \\
(46.51)\end{array}$ & $\begin{array}{c}62.66 \\
(52.31)\end{array}$ & $\begin{array}{c}33.78 \\
(33.75)\end{array}$ & 1.71 & 0.41 \\
\hline Overall mean & & $\begin{array}{l}3.09 \\
(9.96)\end{array}$ & $\begin{array}{c}25.96 \\
(30.44)\end{array}$ & $\begin{array}{c}43.78 \\
(41.30)\end{array}$ & $\begin{array}{c}60.34 \\
(52.03)\end{array}$ & $\begin{array}{c}69.64 \\
(57.93)\end{array}$ & $\begin{array}{c}80.94 \\
(67.11)\end{array}$ & & & \\
\hline $\mathrm{CDp} \geq 0.05$ & 1.52 & & $\begin{array}{l}\text { of plant } \\
\text { s of obser } \\
\text { of plant } x\end{array}$ & ans of obse & & $\begin{array}{l}\mathrm{CDp} \geq 0.05 \\
0.89 \\
0.89 \\
2.20\end{array}$ & $\begin{array}{l}\text { S.I } \\
0.45 \\
0.45 \\
1.10\end{array}$ & & $\begin{array}{l}\text { CD p } \geq 0.05 \\
0.02 \\
\text { S.E(d) } 0.01\end{array}$ & $\begin{array}{l}0.02 \\
0.01\end{array}$ \\
\hline
\end{tabular}

Figures in parentheses are arcsine transformed values 
Plate.1 Effect of plant age on the development of bacterial spot in bottle gourd

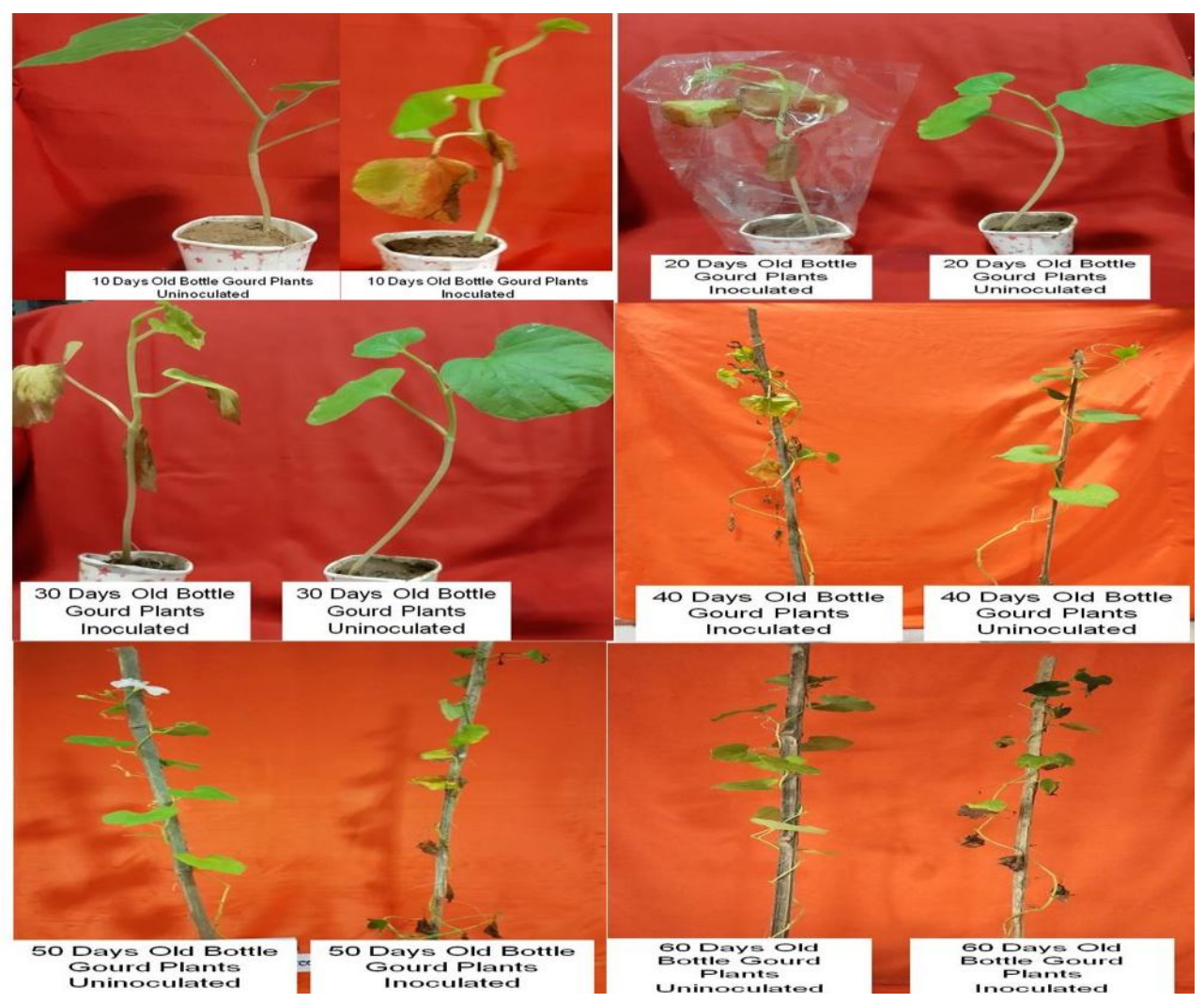

Plate.2 Effect of plant age on the development of bacterial spot in pumpkin

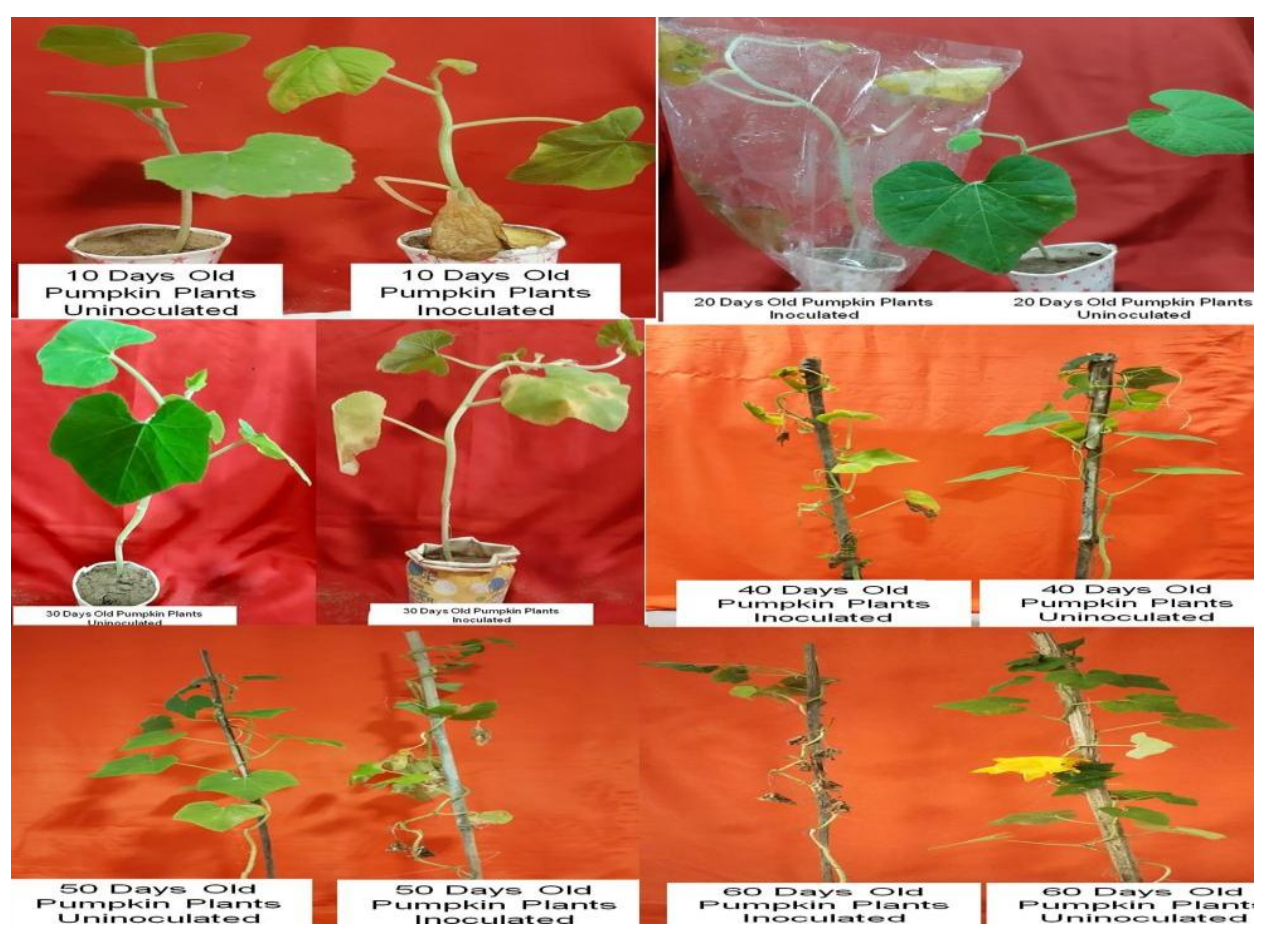


Irrespective of the age of the plants, minimum disease severity $(5.01 \%)$ was recorded on first day of observation i.e. 0 days after symptom appearance which increased significantly on each interval of observation and reached maximum (78.63\%) on last day of observation i.e. 10 days after disease appearance.

Body of the table revealed that disease severity was minimum $(2.50 \%)$ on 0 day after disease appearance in 60 days old plants which was statistically at par with the disease severity in 30 days old plants on the same day (3.33\%). On the last day of observation i.e. 10 days after disease appearance, disease severity was recorded to be significantly maximum $(98.33 \%)$ in 10 days old plants followed by 20 (91.33\%), 30 (88.14\%), 40 (66.66\%), $50(64.66 \%)$ and $60(62.66 \%)$ days old plants on the same day. An intermediate level of disease severity was recorded on other days of observation in plants of different age groups. It is evident from the data that AUDPC was significantly minimum (1.73) in 60 days old plants followed by 50 days old plants (1.97). However, AUDPC was recorded to be significantly maximum (3.06) in 10 days old plants followed by 20 days old plants (2.75). As far as apparent infection rate was concerned, it was significantly minimum ( 0.31 per unit per day) in 60 days old plants followed by the apparent infection rate in 50 days old plants (0.33 per unit per day). However, maximum (0.66 per unit per day) apparent infection rate was recorded in 10 days old plants followed by 20 days old plants (0.54 per unit per day).

Data recorded in terms of incubation period, disease severity and calculated AUDPC as well as apparent infection rate in relation to effect of plant age of pumpkin have been presented in Table 2. It is clear from the table that mean incubation period was significantly minimum $(48 \mathrm{~h})$ in 10 days old plants followed by that recorded in 20 days old plant $(49.66 \mathrm{~h})$. Although, maximum incubation period $(72.00 \mathrm{~h})$ was recorded in 60 days old plant which was statistically at par with incubation period $(71.33 \mathrm{~h})$ recorded in 50 days old plants followed significantly by 40 $(63.33 \mathrm{~h})$ and $30(51.33 \mathrm{~h})$ days old plants.

As far as disease severity was concerned, irrespective of days of observations, mean disease severity was maximum $(65.33 \%)$ in 10 days old plants followed by 20 days old plants $(56.55 \%)$. Significantly minimum mean disease severity $(33.78 \%)$ was recorded in 60 days old plants followed by disease severity in 50 (36.28\%), 40 (40.39\%) and 30 $(51.42 \%)$ days old plant (PLATE 2). However, irrespective of age of plant, minimum mean disease severity $(3.09 \%)$ was recorded after 0 days of disease appearance which increased significantly after each interval of observation and reached maximum $(80.94 \%)$ on last day of observation i.e. after 10 days of disease appearance. Body of the table reveals that minimum mean disease severity $(1.93 \%)$ was recorded in 60 days old plant on 0 day after disease appearance which was statistically at par with disease severity recorded in $50(2.00 \%)$ and 40 days $(2.33 \%)$ old plants on the same day. However maximum mean disease severity (98.33\%) was recorded in 10 days old plant after 10 days of disease appearance which was statistically at par with disease severity (97.32\%) recorded in 20 days old plant on the same day. Disease severity of intermediate range was recorded in the plants of different age groups on rest of the days of observation.

As far as AUDPC was concerned, significantly minimum AUDPC (1.71) was recorded in 60 days old plants followed by 50 days old plants (1.86). However, maximum AUDPC (3.38) was recorded in 10 days old plants followed by 20 days old plants (2.88). It is evident from the data that apparent 
infection rate was significantly minimum (0.41 per unit per day) in 60 days old plants followed by 50 days old plants $(0.44$ per unit per day). However, maximum apparent infection rate (0.72 per unit per day) was recorded in 10 days old plants followed by 20 days old plants ( 0.65 per unit per day).

The growth stage of the plant at the time of pathogen inoculation decides the plant response towards pathogen attack (Whalen, 2005). Generally, there is an increase in incubation period and decrease in disease severity of any disease with increase in age (Kendrick and Walker, 1948). Similar trend was recorded during present investigations on the effect of plant age on disease development in bottle gourd and pumpkin where, incubation period increased and disease severity, AUDPC as well as apparent infection rates decreased with the increase in plant age. Although, the information on the infection efficiency of $X$. cucurbitae on the cucurbit plants of different age groups is not available in the literature but, many workers working on different diseases caused by Xanthomonas spp. have reported that the plants are more susceptible at their early growth stages and become less susceptible with increase in age (Verma, 2001; Wang et al., 2009 and Lamichhane et al., 2013). This decreased susceptibility of plants of higher age groups can be termed as adult plant resistance which might be due to delayed expression of some genes responsible for plant defense and / or accumulation of toxic compounds in the host plant with the development of plant life cycle (Kus et al., 2002).

\section{References}

Alippi A M. (1989). Characterization of Xanthomonas campestris pv. cucurbitae causal agent of bacterial leaf spot of squash. Riv. Argent. Microbiol. 21(1),
15-19.

Altin, I., Casoli, L., and Stefani, E. (2020). First report of bacterial spot caused by Xanthomonas cucurbitae on pumpkin in Italy. New Dis. Rep. 41, 21. http://dx.doi.org/10.5197/j.20440588.2020.041.021.

Anonymous. (1975). Vegatables. Australia, Queensland Department of Primary Industries: Annual Report 1974-75, $51 \mathrm{p}$.

Babadoost, M. and Ravanlou, A. (2012). Outbreak of bacterial spot (Xanthomonas cucurbitae) in pumpkin fields in Illinois. Plant Dis. 96, 1222.

Belete, T. and Bastas, K.K. (2017). Common bacterial blight (Xanthomonas axonopodis pv. phaseoli) of beans with special focus on Ethiopian condition. J. Plant Pathol. Microbiol. 8(3), 403.doi: 10.4172/2157-7471.1000403

Bryan, M.K. (1930). Bacterial leaf spot of squash. J. Agri. Res. 40(4), 385-391.

Dhingra, O.D., and Sinclair, J.B. (2017). Basic Plant Pathology Methods. CRC Press, Boca Raton, FL, USA, 448p.

Dutta, B., Gitaitis, R.D., Lewis, K. J., and Langston, D.B. (2013). A new report of Xanthomonas cucurbitae causing bacterial leaf spot of watermelon in Georgia, USA. Plant Dis. 97, 556.

Farber, D.H., and Mundt, C.C. (2017). Effect of plant age and leaf position on susceptibility to wheat stripe rust. Phytopathology 107, 412-417.

Jarial, K., Dogra, B.S., Mandradia, R.K., Kumar, S., Sharma, D., and Gupta, A.K. (2011). Investigations on a new bacterial disease of bottle gourd in subtropical zone of Himachal Pradesh. Plant Dis. Res. 26(1), 68-75.

Kendrick, J.J., and Walker, J. (1948). Predisposition of tomato to bacterial canker. J. Agri. Res. 77, 169-86.

Kus, J.V., Zaton, K., Sarkar, R., and Cameron, R. K. (2002). Age related 
resistance in Arabidiopsis is developmentally regulated defense response to Pseudomonas syringae The Plant Cell 14, 479-490.

Lamichhane, J.R., Fabi, A., Ridolfi, R., and Varvaro, L. (2013). Epidemiological study of hazelnut bacterial blight in central Italy by using laboratory analysis and geostatistics. PLoS ONE 8 (2), e56298.

Lamichhane, J.R., Varvaro, L., and Balestra, G.M. (2010). Bacterial leaf spot caused by Xanthomonas cucurbitae reported on pumpkin in Nepal. New Dis. Rep. 22, 20.

Larazev, A.M. (2009). Diseases: Xanthomonas campestris pv.cucurbitae (Bryan) Dye-bacterial leaf spot of cucurbits. In: 2003-2009 Project "Interactive agricultural ecological Atlas of Russia and neighbouring countries: economic plants and their diseases, pests and weeds". http://www.agroatlas.ru/en/content/dise ases/Cucurbitae/Cucurbitae_Xanthomo nas_campestris_pv_cucurbitae/

Last, F.T. (1959). Leaf infection of cotton by Xanthomonas malvacearum (E.F.Sm.) Dowson. Ann. App. Biol. 47(4), 647657.

Li, Y.H. (1990). Identification of the pathogen of bacterial leaf spot of cucumber. Acta Phytopathol. Sinica 20(2), 146.

Liu, Q., Ravanlou, A., and Babadoost, M. (2016). Occurrence of bacterial spot on pumpkin and squash fruit in the north central region of the United States and bacteria associated with the spots. Plant Dis. 100, 2377-2382.

Maringoni, A.C., Leite, R.P.Jr., and Komori, N. (1988). A new disease of cucumber (Cucumis sativus L) caused by Xanthomonas campestris pv. cucurbitae (Bryan) Dye in Brazil. Summa Phytopathologica 14, 225-230.
Mew, T.W., Vera Cruz, C.M., and Reyes, R.C. (1981). Characterization of resistance in rice to bacterial blight. Annu. Phytopathol. Soc. Japan 47, 5867.

Mitchell, D.J., Kaanwischer, M.E., and Moore, E.S. (1978). Relationship of numbers of zoospores of Phytophthora cryptogea to infection and mortality of watercress. Phytopathology 68, 14461448.

Neves, D.A., Guimaraes, L.M.S., Ferraz, H.G.M., and Alfenas, A.C. (2014). Favorable conditions for Xanthomonas axonopodis infection in Eucalyptus spp. Trop. Plant Pathol. 39(6), 1983-2052.

Pruvost, O., Robène-Soustrade, I., Ah-You, N., Jouen, E., Boyer, C., Wuster, G., Hostachy, B., Napoles, C., and Dogley, W. (2009). First report of Xanthomonas cucurbitae causing bacterial leaf spot of watermelon in the Seychelles. Plant Dis. 93(6), 671.

Robbs, C.F., Kumura, D., and Barbosa, G.A.A. (1972). Bacterial blight of squash, a disease new to Brazil. Arquivos do Universida de Federal Rural do Rio de Janeiro 2(2), 105-106.

Shanner, G. and Finney, R.E. (1977). The effect of nitrogen fertilization on the expression of slow mildewing resistance in knox wheat. Phytopathology 67, 1051- 1056.

Sinha, P.P. (1989). Preliminary studies on bacterial leaf spot of cucumber. Indian Phytopathology 42, 146 - 149.

Taketani, K., Tamura, M., and Wakimoto, S. (1976). Studies on fruit spot of prince melon III: scab like spots caused by Xanthomonas cucurbitae (Bryan) Dowson. Proc. Assoc. Plant Prot. Hokuriku 24, 63-67.

Van der Plank J.E. (1963). Plant Disease: Epidemics and Control. Academic Press, New York, 349 p.

Verma, K. (2001). Studies on black rot of 
cauliflower caused by Xanthomonas campestris pv. Campestris (Pam) Dowson. Ph.D Thesis, Dr Yashwant Singh Parmar University of Horticulture and Forestry; Solan, $118+x+$ II $p$.

Wang, C., Wen, G., Lin, X., Liu, X., and Zhang, D. (2009). Identification and fine mapping of the new bacterial blight resistance gene, Xa31 (t), in rice. Eur. J. Plant Pathol. 123(2), 235-240. http://dx.doi.org/10.1007/s10658-0089356-4

Whalen, M.C. (2005). Host defence in a developmental context. Mol. Plant Pathol. 6, 347-360.

William, R.H., and Zitter, T.A. (1996). Bacterial Leaf Spot: Compendium of Cucurbits Diseases. American Phytopathological Society, St. Paul M $\mathrm{N}, 35 \mathrm{p}$.

\section{How to cite this article:}

Arpana Sharma, Kumud Jarial and Jarial, R. S. 2020. Effect of Plant Age on the Bacterial Spot of Bottle Gourd and Pumpkin Caused by Xanthomonas cucurbitae. Int.J.Curr.Microbiol.App.Sci. 9(12): 2205-2213. doi: https://doi.org/10.20546/ijcmas.2020.912.260 